\title{
Patogenisitas Beauveria bassiana (Bals.) Viull. yang Diisolasi dari Beberapa Jenis Inang Terhadap Kepik Hijau, Nezara viridula L. (Hemiptera: Pentatomidae)
}

\author{
Parluhutan Siahaan ${ }^{1 *}$, Jusak Wongkar ${ }^{2)}$,Susan Wowiling ${ }^{2)}$ Rowland Mangais ${ }^{1)}$ \\ ${ }^{1)}$ Jurusan Biologi, Fakultas Matematika dan Ilmu Pengetahuan Alam, \\ Universitas Sam Ratulangi, Manado, Indonesia \\ ${ }^{2}$ B) Balai Perlindungan dan Pengujian Mutu Tanaman Pangan dan Hotikultura, Dinas Pertanian dan \\ Peternakan Daerah Provinsi Sulawesi Utara, Manado, Indonesia \\ *Corresponding Author : luhut.siahaan68@unsrat.ac.id
}

\begin{abstract}
ABSTRAK
Kepik Hijau (Nezara viridula L.) merupakan hama penting bagi beberapa tanaman pangan seperti kedelai, padi dan jagung. Salah satu upaya untuk mengendalikan hama adalah dengan pemanfaatan entomopatogen, seperti virus, bakteri maupun jamur. Salah satu jamur entomopatogen yang berpotensi untuk dieksploitasi adalah Beauveria bassiana yang mempunyai berbagai jenis inang. Belum diketahui patogenesitas $B$. bassiana yang diisolasi dari beberapa jenis inang terhadap hama kepik hijau ( $N$. viridula), untuk itulah penelitian ini dilakukan dengan tujuan untuk mengetahui patogenesitas $B$. bassiana yang diisolasi dari inang yang berbeda terhadap hama kepik hijau (N. viridula). Penelitian ini dilakukan di Laboratorium Agens Hayati (LAH) Kalasey, Balai Perlindungan dan Pengujian Mutu Tanaman Pangan dan Hortikultura (BPPMTPH), Dinas Pertanian dan Peternakan Daerah Provinsi Sulawesi Utara. Penelitian dilakukan secara invitro dengan menggunakan Rancangan Acak Lengkap (RAL) dengan 6 perlakuan yaitu (Kontrol negatif , N1: suspensi B. bassiana isolat WBC (wereng batang coklat), N2: suspensi B. bassiana isolat Jati Sari sebagai kontrol positif (rekomendasi Kementan), N3: suspensi B. bassiana isolat Paraeucosmetus pallicornis (kepik hitam), N4: suspensi B. bassiana isolat Leptocorisa acuta (walang sangit) dan N5: suspensi B. bassiana isolat Scotinopara coarctata (kepinding tanah). Perlakuan menggunakan konsentrasi atau kerapatan konidia $10^{9} / \mathrm{ml}$ air, dengan 5 ulangan. Data dianalisis dengan Uji Anava 95\% dan analisis probit untuk menentukan $\mathrm{LT}_{50}$ (Lethal Time 50). Hasil penelitian menunjukkan bahwa jamur B. bassiana isolat Jati Sari memiliki patogenisitas tertinggi dengan membunuh kepik hijau ( $N$. viridula) sampai 100\% pada hari ke-5 HSP (hari setelah perlakuan), sedangkan isolat lain semuanya pada hari ke-6 HSP. Nilai LT $_{50}$ (waktu yang dibutuhkan untuk membunuh 50\% serangga uji) terdapat pada isolat $P$. pallicornis yaitu 2,1 hari. Persentasi mortalitas pada hari ke-3 HSP tertinggi terdapat pada perlakuan isolat $P$. pallicornis dengan rata-rata mortalitas sebesar $78 \%$ diikuti isolat $L$. acuta dan S. coarctata masing-masing sebesar $68 \%$ dan isolat Jati sari sebesar 58\%, sedangkan mortalitas terendah terdapat pada perlakuan isolat WBC yaitu sebesar $32 \%$. Tidak ada perbedaan patogenisitas yang signifikan diantara isolat Jati Sari, P. pallicornis, L. acuta maupun S. coarctata kecuali isolat WBC.
\end{abstract}

Kata kunci: Beauveria bassiana; Entomopatogen; Nezara viridula

\section{Pathogenicity of Beauveria bassiana (Bals.) Viull. Isolated from Several Host Species Against Green Ladybug, Nezara viridula L. (Hemiptera: Pentatomidae)}

\begin{abstract}
Green Ladybugs (Nezara viridula L.) are important pests for several food crops such as soybeans, rice and corn. One of the efforts to control this pest is the use of entomopathogens, such as viruses, bacteria and fungi. One of the entomopathogenic fungi that has the potential to be exploited is the fungus Beauveria bassiana. The fungi B. bassiana has various of hosts. There are no data on the pathogenicity of $B$. bassiana isolated from several host species against green ladybugs (Nviridula), for that reason this study was conducted with the aim of knowing the pathogenicity of $B$. bassiana isolated from different hosts against green ladybugs ( $N$. viridula).. This research was conducted at Laboratory of Biological Control Agents, the Center for the Protection and Quality Testing of Food Crops and Horticulture, the Regional Agriculture and Livestock Service Office of
\end{abstract}


North Sulawesi Province. The research was conducted in-vitro using a completely randomized design (CRD) with 6 treatments, namely (Negative control, N1: suspension B. bassiana, WBC isolate (brown planthopper), N2: B. bassiana suspension, Jati Sari isolate as a positive control (Ministry of Agriculture Recommendation), N3 : B. bassiana suspension isolate Paraeucosmetus pallicornis (black ladybug), N4: suspension B. bassiana isolate Leptocorisa acuta (Rice ear bug) and N5: suspension B. bassiana isolate Scotinopara coarctata (rice black bug) Treatment using conidia concentration or density $10^{9} / \mathrm{ml}$ water, with 5 replications. Data were analyzed with Anava test $95 \%$ and probit analysis to determine $\mathrm{LT}_{50}$ (Lethal Time 50). The results showed that the fungus B. bassiana Jati Sari isolate had the highest pathogenicity, because this isolate was able to kill green ladybugs ( $N$ viridula) to $100 \%$ on the 5 th day of DAT (the day after treatment), while the other isolates were all on the 6th DAT. While the value of $\mathrm{LT}_{50}$ (time needed to kill $50 \%$ of the insect test) was found in P. pallicornis isolates which were 2,1 days of DAT. Because $\mathrm{LT}_{50}$ in all isolate treatments was between the 2nd and 3rd day of DAT, the Anava test for mortality was carried out on the 3rd day of DAT. The highest percentage of mortality on the 3rd day of DAT was found in the treatment of $P$. pallicornis isolates with an average mortality of $78 \%$ followed by L. acuta and S. coarctata isolates each at $68 \%$ and Jati sari isolates at $58 \%$, while the lowest mortality was found in the treatment of WBC isolates, namely $32 \%$. There was no significant difference in pathogenicity between Jati Sari, P. pallicornis, L. acuta and S. coarctata isolates except for WBC isolates.

Keywords: Beauveria bassiana; Entomopatogen; Nezara viridula

(Article History：Received 11-11-2020; Accepted 27-02-2021; Published 06-03-2021)

\section{PENDAHULUAN}

Kepik Hijau (Nezara viridula L.) merupakan salah satu hama polifag terbesar di dunia yang berkembang baik di daerah tropis dan subtropis benua Eropa, Asia, Afrika dan Amerika (Knight \& Gurr, 2007). Kepik hijau menjadi hama penting bagi beberapa tanaman pangan seperti kedelai, padi dan jagung. Kepik hijau juga menyerang tanaman kacang panjang, cabai, kapas, jeruk dan tanaman polong lainnya (Prayogo, 2013). Nimfa dan imago kepik hijau merusak tanaman dengan dengan cara menusukkan stiletnya pada buah dan biji dari tanaman lalu menghisap cairan pada buah dan biji sehingga mengakibatkan kerusakan (Afrinda et al., 2014). Stadia nimfa maupun imago hama kepik hijau mempunyai peluang yang sama besar dalam menyebabkan kerusakan tanaman, dimana kehilangan hasil akibat serangan hama kepik hijau dapat mencapai 80\% (Correra \& Azevedo, 2002).

Pengendalian hama kepik hijau yang dilakukan oleh petani pada umumnya masih menggunakan pestisida sintetik yang dilakukan secara intensif. Penggunaan pestisida sintetik secara terus-menerus dapat menimbulkan berbagai dampak negatif, diantaranya terbunuhnya musuh alami dan akumulasi residu pestisida (Suprayogi et al., 2015). Salah satu alternatif yang dilakukan untuk mengurangi dampak negatif penggunaan pestisida sintetik agar aman bagi lingkungan, adalah dengan pengendalian hama terpadu (PHT) meliputi pengendalian secara kultur teknis dan pengendalian hayati, sedangkan pestisida hanya digunakan bila perlu (Hasna et al., 2012).

Salah satu komponen dalam PHT adalah pemanfaatan entomopatogen. Entomopatogen merupakan salah satu jenis bioinsektisida yang dapat digunakan untuk mengendalikan hama tanaman. Jamur entomopatogen yang sudah diketahui efektif mengendalikan hama penting pada tanaman pertanian adalah B. bassiana (Bals.) Viull. Pemanfaatan jamur entomopatogen dalam pengendalian hama karena mempunyai kelebihan yaitu kapasitas reproduksi yang tinggi, siklus hidupnya pendek, dapat membentuk spora yang tahan lama di alam walaupun dalam kondisi yang tidak menguntungkan (Afrinda et al., 2014). Jamur $B$. bassiana dilaporkan sebagai agensi hayati yang tersebar luas dan sangat efektif mengendalikan sejumlah spesies serangga hama termasuk rayap, kutu putih dan beberapa jenis kumbang (Soetopo \& Indrayani, 2007).

Hasil penelitian Brotodjojo et al. (2020), Aplikasi B. bassiana dengan konsentrasi $30 \mathrm{~g} / \mathrm{L}$ terhadap Hypothenemus hampei menghasilkan mortalitas tercepat (Mortality time and Lethal Time 50\%) yaitu 
pada 14,14 hari setelah perlakuan. Penelitian yang dilakukan oleh Bayu \& Prayogo (2017) menunjukkan bahwa aplikasi B. Bassiana sebanyak empat sampai enam kali dapat menekan populasi Empoasca sp., Riptortus linearis, dan Maruca testulalis. Hasil penelitian Hajek et al. (2020) menemukan bahwa aplikasi tunggal $B$. bassiana mengurangi nimfa $L$. delicatula instar keempat sebesar 48\% setelah 14 hari. Aplikasi B. bassiana pada L. delicatula dewasa di taman yang sama menghasilkan $43 \%$ kematian setelah 14 hari. Penelitian Permadi et al. (2019) menemukan bahwa aplikasi $B$. Bassiana menyebabkan kematian terhadap hama $N$. viridula sebesar 66,67\%.

Penelitian-penelitian mengenai patogenitas $B$. bassiana terhadap kepik hijau dan serangga-serangga lain telah banyak dilakukan, namun belum diketahui bagaimana patogenesitas $B$. bassiana yang diisolasi dari jenis inang yang berbeda dan diaplikasikan terhadap kepik hijau. Penelitian ini bertujuan untuk mengetahui patogenesitas $B$. bassiana yang diisolasi dari inang yang berbeda terhadap hama kepik hijau ( $N$. viridula).

\section{METODE PENELITIAN}

Penelitian ini telah dilaksanakan pada bulan Juli-Agustus 2020 di Laboratorium Agens Hayati (LAH), Balai Perlindungan dan Pengujian Mutu Tanaman Pangan dan Hortikultura (BPPMTPH), Dinas Pertanian dan Peternakan Daerah Provinsi Sulawesi Utara. Alat yang digunakan adalah erlenmeyer, gelas ukur, botol plastik, shaker, handsprayer, autoclaf, lampu bunsen, laminar air flow, petridish, saringan, pipet tetes, haemocytometer.

Penelitian dilakukan secara in-vitro dengan menggunakan Rancangan Acak Lengkap (RAL) dengan 6 perlakuan yaitu:

1) Kontrol negatif,

2) WBC: B. bassiana isolat WBC (wereng batang coklat),

3) JS: B. bassiana isolat Jati Sari sebagai kontrol positif (rekomendasi Kementan),

4) PP: B. bassiana isolat P. pallicornis (kepik hitam),

5) LA: B. bassiana isolat $L$. acuta (walang sangit) dan

6) SC: B. bassiana isolat $S$. coarctata (kepinding tanah).
Perlakuan menggunakan konsentrasi atau kerapatan konidia $10^{9} / \mathrm{ml}$ air, dengan 10 ekor kepik hijau nimfa instar III dan 5 ulangan.

\section{Perkembangbiakan Serangga Kepik Hijau}

Kelompok nimfa maupun imago kepik hijau diperoleh dari lahan pertanaman cabai di kebun percobaan (KP) Balai Perlindungan Tanaman Pangan dan Hortikultura Desa Kalasey. Kelompok nimfa pada isntar III yang diperoleh dari lapangan kemudian dimasukkan ke dalam kurungan kain kasa untuk dilakukan rearing. Setiap kurungan diisi tanaman cabai yang terbebas dari residu insektisida kimia. Nimfa maupun imago kemudian dipelihara di dalam rumah kaca. Masing-masing stadia nimfa yang umurnya sama dimasukkan ke dalam satu kurungan untuk menghindari kompetisi antar umur stadia serangga. Selanjutnya, 10 ekor nimfa instar tiga diamasukan kedalam botol plastik yang berisi daun dan buah cabai yang sudah dicuci bersih untuk pakan nimfa.

\section{Perbanyakan Jamur Entomopatogen $B$. bassiana}

Isolat Jamur $B$. bassiana yang digunakan sebagai perlakuan adalah hasil eksplorasi di Kecamatan Dumoga Kabupaten Bolaang Mongondow Provinsi Sulawesi Utara pada tahun 2020 berasal dari serangga Nilaparvata lugens, Leptocorisa sp, Paraeucosmetus sp dan Scotinopara sp. Isolat Jamur B. Bassiana yang berasal dari Jati Sari digunakan sebagai pembanding. Isolat Jamur dikulturkan pada media potato dextrose agar (PDA) di dalam cawan Petri. Setelah berumur 14 hari setelah inokulasi (HSI), isolat Jamur diperbanyak pada media beras dengan tujuan untuk memproduksi konidia dalam jumlah yang optimal. Beras sebagai calon media tumbuh sebelumnya dicuci menggunakan air, setelah bersih kemudian direndam di dalam air selama dua jam. Setelah direndam, dimasukkan ke dalam kantong plastik kemudian diikat. Media beras disterilisasi di dalam autoclave pada temperatur $121^{\circ} \mathrm{C}$ selama 30 menit kemudian dibiarkan hingga dingin. Setiap kantong plastik yang berisi media beras diinokulasi dengan suspensi $B$. bassiana pada $100 \mathrm{~g}$ media.

\section{Aplikasi Suspensi Konidia Jamur B. bassiana}

Jumlah konidia dihitung menggunakan 
haemocytometer hingga memperoleh kerapatan konidia $10^{9} / \mathrm{ml}$. Biakan Jamur $B$. bassiana dengan kerapatan konidia $10^{9} / \mathrm{ml}$, selanjutnya dimasukkan ke dalam erlenmeyer yang dicampur dengan air kemudian dikocok menggunakan shaker selama kurang lebih 30 menit dengan tujuan merontokkan konidia yang terbentuk. Selanjutnya disaring menggunakan kain kasa halus untuk memisahkan konidia dengan media biakan jamur. Aplikasi pada masing-masing perlakuan dilakukan pada sore hari dengan cara menyemprotkan suspensi konidia sebanyak $10 \mathrm{ml}$ pada serangga uji sebanyak 1 kali. Setiap dua hari, cabai sebagai pakan nimfa yang diuji diganti dengan cabai yang segar.

\section{Pengamatan dan Analisi Data}

Pengamatan dilakukan setiap hari dengan menghitung mortalitas nimfa setelah disemprot jamur $B$. bassiana. Data yang diperoleh dianalisis dengan SPSS, untuk mencari $\mathrm{LT}_{50}$ (Lethal Time 50) menggunakan analisis probit dan analisis varian dengan uji Anava. Bila ada perbedaan antara perlakuan dilanjutkan dengan uji beda nyata terkecil pada taraf $\alpha$ $5 \%$.

\section{HASIL DAN PEMBAHASAN}

\section{Mortalitas}

Jamur entomopatogen $B$. bassiana mampu menginfeksi serangga kepik hijau $(N$. viridula), dan mempengaruhi mortalitas dari kepik hijau. Rata-rata mortalitas kepik hijau untuk setiap perlakuan isolat $B$. bassiana dapat dilihat pada Gambar 1.

Gambar 1 menunjukkan rata-rata mortalitas kepik hijau untuk setiap isolat $B$. bassiana dari hari ke-1 sampai ke-6 HSP (hari setelah perlakuan). Hari pertama HSP menunjukkan bahwa $B$. bassiana isolat $L$. acuta, $S$. coarctata dan $P$. pallicornis telah mampu membunuh kepik hijau dengan mortalitas diatas $20 \%$, berbeda dengan isolat Jati Sari dan WBC yang pada hari pertama setelah perlakuan belum mampu membunuh serangga kepik hijau. Isolat WBC menunjukkan mortalitas yang lebih lambat dibandingkan dengan isolat lainya, sedangkan isolat Jati Sari menunjukkan mortalitas yang lambat di hari pertama dan kedua, tetapi mengalami percepatan pada hari ketiga sampai hari kelima. Isolat Jati Sari hanya membutuhkan waktu lima hari setelah aplikasi untuk membunuh kepik hijau dengan presentasi $100 \%$, dibandingkan dengan isolat lainnya yang membutuhkan waktu enam hari untuk membunuh kepik hijau hingga $100 \%$.

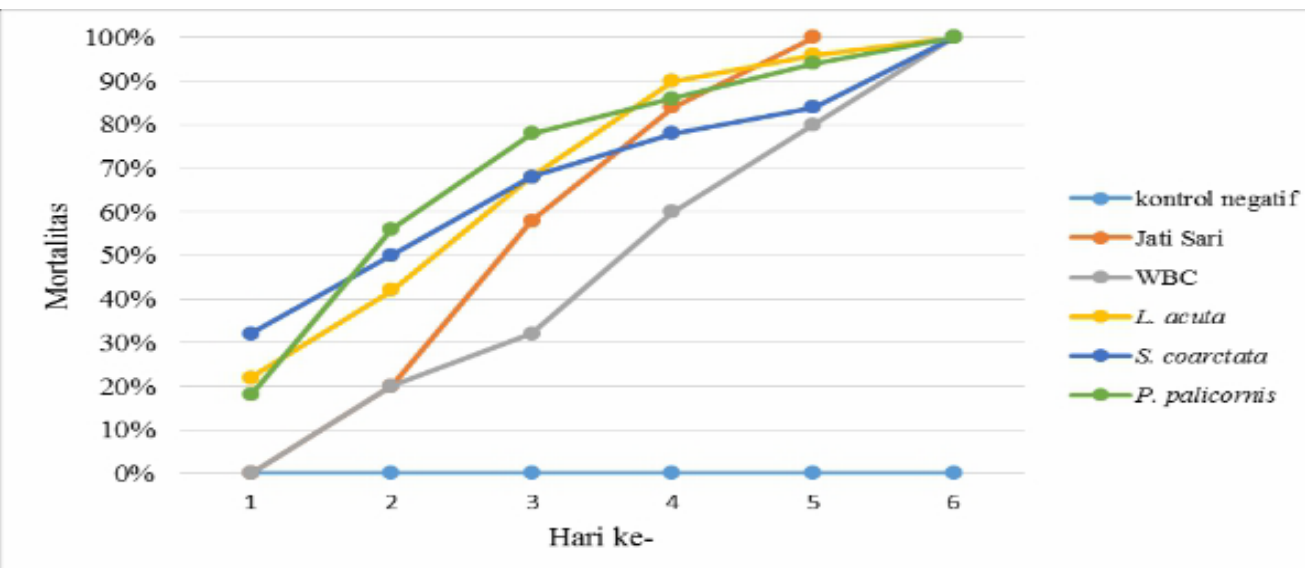

Gambar 1. Grafik persentase mortalitas kepik hijau (N. viridula) setelah aplikasi beberapa isolat B. bassiana 


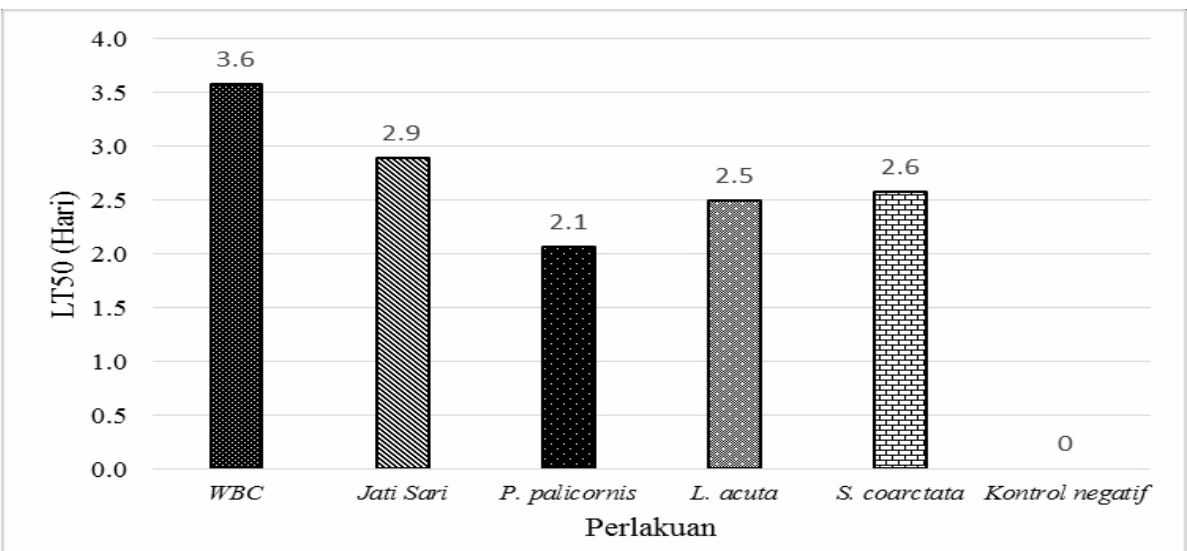

Gambar 2. Nilai $\mathrm{LT}_{50}$ perlakuan isolat WBC, Jati Sari, P. pallicornis, L. acuta, S. coarctata dan Kontrol

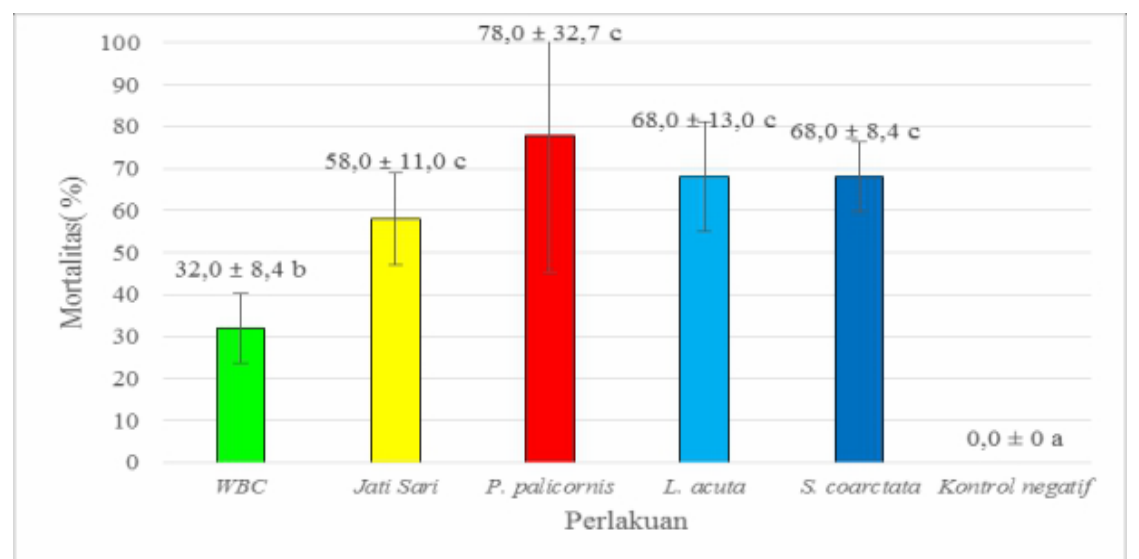

Gambar 3. Hasil analisis terhadap presentase kematian pada hari ketiga; Huruf kecil yang sama diatas bar menunjukkan tidak berbeda nyata berdasar uji BNT pada $\alpha 5 \%$.

\section{Lethal Time $50\left(\mathbf{L T}_{50}\right)$}

Patogenisitas jamur B. bassiana dapat dinilai berdasarkan waktu yang dibutuhkan untuk membunuh serangga kepik hijau. Nilai $\mathrm{LT}_{50}$ yaitu waktu yang dibutuhkan insektisida untuk dapat mematikan $50 \%$ dari populasi serangga uji setelah jangka waktu tertentu (Gambar 2).

Hasil analisis data menunjukkan tingkat mortalitas tertinggi terdapat pada perlakuan isolat $P$. pallicornis dengan rata-rata mortalitas sebesar $78 \%$, diikuti L. acuta dan S. coarctata sebesar $68 \%$ dan Jati Sari sebesar $58 \%$. Mortalitas terendah terdapat pada perlakuan isolat WBC sebesar $32 \%$ dan pada kontrol negatif yang tidak terdapat serangga yang mengalami kematian.

Nilai $\mathrm{LT}_{50}$ untuk jamur isolat WBC, Jati Sari, $P$. pallicornis, L. acuta dan $S$. cotinopara secara berturut-turut adalah 3,6 hari; 2,9 hari; 2,1 hari; 2,5 hari dan 2,8 hari. Berdasarkan nilai $\mathrm{LT}_{50}$ dari masing-masing isolat didapatkan waktu yang dibutuhkan untuk mematikan serangga uji sebesar 50\% yang tercepat adalah isolat $P$. pallicornis yaitu 2,1 hari. $\mathrm{LT}_{50}$ waktu yang dibutuhkan untuk mematikan serangga uji sebesar 50\% paling lambat pada isolat WBC yaitu 3,6 hari.

Nilai $\mathrm{LT}_{50}$ menunjukkan bahwa kemampuan jamur $B$. bassiana dari kelima isolat memiliki kemampuan patogenisitas yang hampir sama. Hal ini dilihat dari waktu yang dibutuhkan oleh kelima isolat untuk membunuh kepik hijau sebanyak 50\% dari populasi berada pada kisaran dua sampai tiga hari setelah aplikasi. Kemampuan patogenisitas isolat $P$. pallicornis lebih cepat dibandingkan isolat lainnya.

\section{Persentase Mortalitas pada Hari Ketiga}

Analisis rata-rata persentase mortalitas kepik hijau dilakukan pada hari ketiga HSP. Berdasarkan uji Anava ada perbedaan yang signifikan pada rata-rata persentase mortalitas di antara perlakuan. Hasil uji BNT menunujukkan bahwa perlakuan isolat Jati 
Sari, P. pallicornis, L. acuta, dan S. coarctata tidak berbeda nyata, tetapi berbeda nyata dengan isolat WBC dan kontrol negatif (Gambar 3).

Hasil analisis menunjukkan bahwa isolat $P$. pallicornis, $L$. acuta, dan S. coarctata yang diisolasi dari daerah Dumoga mampu menyaingi isolat Jati Sari yang merupakan rekomendasi Kementrian Pertanian sebagai entomopatogen pengendali hama. Jamur B.bassiana mampu menginfeksi dan membunuh stadia nimfa maupun imago. Semakin muda umur nimfa, semakin rentan terhadap infeksi jamur B. bassiana (Prayogo, 2013). Kematian nimfa kepik hijau yang terinfeksi jamur $B$. bassiana mulai terjadi pada satu hari setelah perlakuan (HSP). Pada saat nimfa mengalami kematian belum terdapat tanda-tanda miselium tumbuh pada organ kepik hijau. Miselium jamur $B$. bassiana baru tampak pertama kali pada umur lima hari setelah perlakuan (HSP).

Penularan jamur ini dari satu inang kepada inang yang lainnya dapat terjadi melalui kontak langsung dengan individu yang terinfeksi. Akan tetapi, induk yang sakit tidak menularkannya pada telur yang dihasilkannya. Seperti pada jenis-jenis jamur yang lain, maka jamur $B$. bassiana juga memerlukan suhu dan kelembapan yang cukup baik (favorable) untuk pertumbuhan dan perkembangannya. Suhu optimum untuk pertumbuhan yang baik adalah sekitar $28^{\circ} \mathrm{C}$ (Siahaan \& Saimima, 2020). Tubuh imago yang terinfeksi oleh $B$. bassiana ditandai oleh tumbuhnya miselia berwarna putih (Gambar 4) dan mengeras seperti mumi.

$N$. viridula mulai menunjukan gejala terinfeksi pada $1 \mathrm{HSP}$, hal ini tampak dari tumbuhnya meselia berwarna putih pada kutikula serangga, gangguan motorik seperti kejang-kejang dan gerakan yang menjadi lambat. Siahaan \& Saimima (2020) menjelaskan mekanisme infeksi B. bassiana terhadap serangga dimulai melalui kutikula. Mulamula sporulasi terjadi pada cadaver serangga dan spora terlepas ke udara. Spora akan menempel pada kutikula serangga dan terjadi perkecambahan. Proses inisiasi hifa akan dibantu oleh enzim kitinase dan amilase hingga menembus kedalam epidermis. Selanjutnya enzim lipase dan protease membantu menembus lapisan epidermis menuju hemocoel. Saat inisiasi selesai hifa akan tumbuh membentuk miselium dan melepaskan racun golongan dekstruksin dan mikotoksin sehingga serangga kehilangan kontrol atas tubuhnya, pada tahap lanjut serangga akan mengalami gangguan motorik yang nampak seperti kejang-kejang, gerakan menjadi lambat, dan akhirnya tubuh tidak dapat digerakan. Pada tahap ini miselium akan tumbuh memenuhi bagian dalam tubuh serangga dan berkembang dengan cepat. Proses ini berlanjut sampai serangga benarbenar mati. Miselium akan terus tumbuh sampai menembus ruas-ruas tubuh serangga dan mengalami sporulasi.
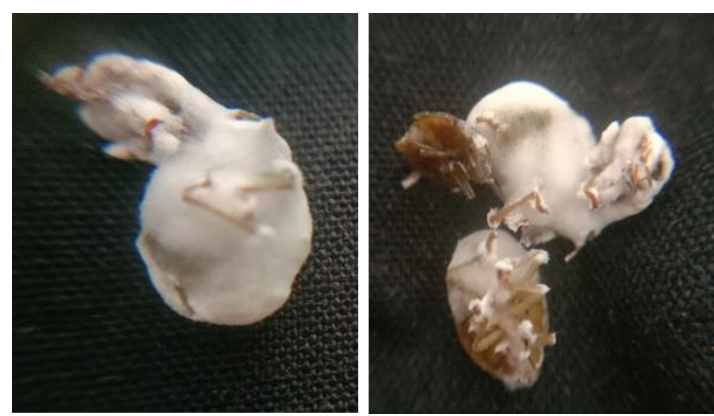

Gambar 4. Nimfa kepik hijau yang dikolonisasi miselium jamur B. bassiana yang berbentuk seperti mumi

Kemampuan B. bassiana dalam mendegradasi dinding integumen serangga diakibatkan oleh kandungan enzim kitinase yang besar, hal ini sesuai dengan beberapa laporan menyebutkan bahwa sebagian besar jamur entomopatogen memiliki kandungan enzim kitinase yang cukup besar sehingga sangat toksik dalam mendegradasi dinding integumen serangga (Fang et al., 2005; Lu et al., 2005; Zhu et al., 2008).

Keberhasilan jamur entomopatogen dalam menginfeksi serangga hama dipengaruhi oleh beberapa faktor diantaranya lingkungan dan viabilitas spora. Jamur entomopatogen untuk dapat berkecambah memerlukan keadaan yang lembab. Selain itu kemampuan jamur entomopatogen dalam menginfeksi hama juga dipengaruhi oleh jumlah spora dan viabilitasnya. Menurut Surtikanti \& Yasin (2009) keberhasilan jamur entomopatogen sebagai pengendali hama dipengaruhi oleh faktor lingkungan (suhu, kelembaban), jumlah spora, viabilitas spora (daya kecambah) dan virulensi yang memiliki infektifitas yang rendah atau sebaliknya.

B. bassiana juga memiliki kemampuan dalam mengendalikan berbagai jenis hama pada tanaman. Hasil penelitian Gargita et al. 
(2017) B. bassiana cukup efektif menginfeksi Helopeltis spp. karena waktu yang diperlukan hanya 4 hari untuk membunuh Helopeltis spp. Pengujian formulasi di lapangan menunjukkan formulasi B. bassiana efektif mengendalikan Helopeltis spp. yaitu pada konsentrasi formulasi 20 gram dilarutkan dalam satu liter air merupakan konsentrasi yang paling baik dengan jumlah cucukan paling sedikit. Hasil penelitian Intarti et al. (2020) mendapatkan aplikasi agen Hayati $B$. bassiana mampu mengendalikan hama Thrips sp. Apliaksi $B$. bassiana konsentrasi $20 \mathrm{ml} \mathrm{L}-1$ dapat efektif mencegah hama Thrips sp. pada tanaman cabai rawit varietas dewata F1 sebesar 99,53\% dibandingkan dengan kontrol negatif. Aplikasi jamur B. bassiana pada taraf konsentrasi $10 \%$ terhadap mortalitas larva efektif dan efisien, karena mampu membunuh larva $76,67 \%$ pada hari ke-7, membuat larva sakit sebanyak 7,67 ekor pada perubahan kesehatan, dan meminimalisir perubahan stadia lanjut larva sebanyak 1,22 ekor (Ardan et al., 2019).

Perlakuan kombinasi antara agensi hayati dan pestisida nabati telah banyak dilakukan, dengan tujuan meningkatkan mortalitas hama target. Hasil penelitian menunjukkan masih sangat sedikit jamur $B$. bassiana yang kompatibel dengan pestisida nabati. Seperti hasil penelitian yang dilakukan Susanti et al. (2016) menemukan bahwa uji kompatibilitas jamur entomopatogen $B$. bassiana dengan pestisida nabati ekstrak daun babadotan tidak kompatibel. Hasil uji menunjukkan bahwa ekstrak daun babadotan menghambat daya kecambah konidia, pertumbuhan koloni, dan sporulasi.

\section{KESIMPULAN}

Hasil penelitian menunjukkan bahwa mortalitas $100 \%$ dicapai pada hari kelima dan keenam HSP. Mortalitas $100 \%$ tercepat terdapat pada kontrol positif, yaitu hari kelima HSP. nilai $\mathrm{LT}_{50}$ dari masing-masing isolat didapatkan berada diantara 2,1 sampai 3,6 hari. $\mathrm{LT}_{50}$ tercepat terdapat pada isolat $P$. pallicornis yaitu 2,1 hari, dan $\mathrm{LT}_{50}$ paling lambat terdapat pada isolat WBC yaitu 3,6 hari. Persentasi mortalitas tertinggi pada hari ketiga HSP terdapat pada perlakuan isolat $P$. palicornis dengan rata-rata mortalitas sebesar
$78 \%$ diikuti isolat $L$. acuta dan $S$. coarctata masing-masing sebesar $68 \%$ dan isolat Jati Sari sebesar $58 \%$, akan tetapi keempat isolat ini tidak berbeda nyata. Mortalitas terendah terdapat pada perlakuan isolat WBC sebesar $32 \%$ yang berbeda nyata dengan isolat lain dan juga kontrol. Isolat lokal yang berasal dari inang $P$. palicornis, L. acuta dan $S$. coarctata memiliki patogenisitas yang sama dengan isolat Jari Sari.

\section{DAFTAR PUSTAKA}

Afrinda, D., Salbiah, D., \& Laoh, J.H. 2014. Uji Beberapa Konsentrasi Beauveria bassiana Vuillemin Lokal Dalam Mengendalikan Hama Kepik Hijau (Nezara viridula L.) (Hemiptera: Pentatomidae) pada Tanaman Kedelai (Glycine max L.). Jurnal Faperta, (1) 2 :1- 10.

Ardan, I. M., Nurdiana, D. \& Maesyaroh, S.S. 2019. Aplikasi Jamur Entomopatogen (Beauveria bassiana) dan Ekstrak Tumbuhan (Ageratum conyzoides L.) terhadap Larva Plutella xylostella L. Jurnal JAGROS, (3)2: 8499.

Bayu, M.S.Y.I. \& Prayogo, Y. 2017. Field efficacy of entomopathogenic fungi Beauveria bassiana (Balsamo.) for the management of mungbean insect pests. International Symposium on Food and Agro-biodiversity (ISFA) ke 2.

Brotodjojo, R.R., Solichah,R., Widyaningtyas, A. \& Wicaksono, D. 2020. Effects of Culture Media on Viability of Beauveria bassiana and Its Pathogenicity Against Coffee Bean Borer (Hyphotenemus Hampei). Proceeding International Conference on Science and Engineering, 3: 49-53.

Fang, W.G., Leng, B., Xiao, Y.H., \& Pei, Y. 2005. Cloning of Beauveria bassiana chitinase gene Bbchit1 and its application to improve fungal strain virulence. Applied and Environmental Microbiology, (71)1 :363-370.

Correra, F.B.S., \& Azevedo, J. 2002. Soybean seed damage by different species of stink bugs. Agricultural and Forest Entomology, (4)2:145-152. 
Gargita, I.W.D., Sudiarta, I.P. \& Wirya, G.N.A. 2017. Pemanfaatan Patogen Serangga (Beauveria bassiana Bals.) untuk Mengendalikan Hama Penghisap Buah Kakao (Helopeltis spp.) di Desa Gadungan, Kecamatan Selemadeg Timur, Kabupaten Tabanan. E-Jurnal Agroekoteknologi Tropika, (6)1:11-20.

Hajek, A.E., Jenkins, N.E., Roush, R.T., Rost, J.P. \& Biddinger, D. J. 2020. Applications of Beauveria bassiana (Hypocreales: Cordycipitaceae) to Control Populations of Spotted Lanternfly (Hemiptera: Fulgoridae), in Semi-Natural Landscapes and on Grapevines. Environmental Entomology, 49(4) : 854-864.

Hasnah, Sussana \& Husin, S. 2012. Keefektifan Jamur Beauveria bassiana Vuill terhadap Mortalitas Kepik Hijau Nezara viridula L. pada Stadia Nimfa dan Imago. Jurnal Floratek, (7)1: 13-24.

Intarti, D.Y., Kurniasari, I. \& Sudjianto, A. 2020. Efektivitas Agen Hayati Beauveria bassiana dalam Menekan Hama Thrips sp. pada Tanaman Cabai Rawit (Capcisum frutescens L.). Jurnal Agrovigor, 13(1):10-15.

Knight, K.M.M. \& Gurr GM. 2007. Review of Nezara viridula (L.) management strategies and potential for IPM in field crops with emphasis on Australia. Crop Protection, 26(1):1-10.

Lu, Z.X., Laroche, A. \& Huang, H.C. 2005. Isolation and characterization of chitinase from Verticillium lecanii. Canadian Journal of Microbiology, (51)12:10451055.

Permadi, M.A., Lubis, R.A., Mukhlis, Pahlawan, L.A. \& Abdi, S. 2019. Efication of Some Entomopatogen Fungus on Green Ladybug Imago (Nezara Viridula Linnaeus) (Hemiptera: Pentatomidae). Budapest International Research in Exact Sciences (BirEx) Journal, (1)2: 21-28.

Prayogo, Y. 2013. Patogenisitas Jamur Entomopatogen Beauveria bassiana (Deuteromycotina: Hyphomycetes) pada Berbagai Stadia Kepik Hijau (Nezara viridula L.). Jurnal HPT Tropika, (13)1: 75-86.
Siahaan, P. \& Saimima, A. 2020. AgensAgens Hayati Sebagai Pengganti Insektisida Sintetik. Patra Media Grafindo, Bandung.

Soetopo, D. \& Indrayani, I. 2007. Status Teknologi dan Prospek Beauveria bassiana Untuk Pengendalian Serangga Hama Tanaman Perkebunan Yang Ramah Lingkungan. Jurnal Perspektif, (6)1: 29-46.

Suprayogi, Marheni, \& Oemry, S. 2015. Test Effectivity of Fungi Entomopathogen Beauveria bassiana and Metarhizium anisopliae Against Green Stink Bug (Nezara viridula L.) (Hemiptera: Pentatomidae) in Soybean (Glicyne max L.) at Screen House. Jurnal Online Agroekoteknologi, (3)1: 320327.

Surtikanti \& Yasin, M. 2009. Keefektifan Entomopatogenik Beauveria bassiana Vuill. Dari Berbagai Media Tumbuh terhadap Spodoptera litura F. (Lepidoptera: Noctuidae) di Laboratorium. Balai Penelitian Tanaman Serelia. Prosiding Seminar Nasional Serelia.

Susanti, S., Wibowo, L. \& Indriyati. 2016. Kompatibilitas Jamur Entomopatogen Beauveria bassiani Vuill. Dan Pestisida Nabati Ekstrak Daun Babadotan untuk Mengendalikan Hama Kepik Hijau di Laboratorium. J. Agrotek Tropika, 4(1): 49-54.

Zhu, Y., Pan, J., Qiu, J. \& Guan, X. 2008. Isolation and characterization of a chitinase gene from entomopathogenic fungus Verticillium lecanii. Brazilian Journal of Microbiology, (39)2: 314320. 